\title{
Gentlemen and shopkeepers: supplying the country house in eighteenth-century England
}

\begin{abstract}
The country house is well recognised as a site of elite patronage, an important vehicle of social and political ambition, and a statement of power and taste. Yet we know relatively little about the networks of supply and purchasing patterns of rural elites, or about how their practices related to broader changes in material culture. Drawing on a large sample of bills and receipts of the Leigh family of Stoneleigh in Warwickshire, this paper recreates the processes through which the material culture of the family home was constructed. These reveal London as the source for many high quality goods, although the pattern of supply was not a simple dichotomy of local-everyday and metropolitan-luxury purchases. They also show the large number of shopkeepers patronised as the Leighs spread their purchases through choice, convenience and expediency. Relating this to wider conceptions of consumption, the Leighs emerge as engaging in layered and sometimes conflicting consumer cultures. They were concerned with fashion as novelty and a marker of rank; but they also valued traditional markers of status. Social distinction was achieved through a continued emphasis on title and lineage as much as fashion or taste - value systems that were unavailable the middling sorts.
\end{abstract}




\section{Gentlemen and shopkeepers: supplying the country house in eighteenth-century England ${ }^{1}$}

In recent years, consumption has emerged as a meta-narrative of historical enquiry, especially for the eighteenth century where it has eclipsed production and industrialisation as the dominant explanatory framework for social, cultural and economic transformation. ${ }^{2}$ Part of this growing domination comes from the broad and malleable nature of consumption as a concept and process. It has been variously portrayed as the ownership and meaning of goods; the use of leisure time, and the means by which goods were acquired and ideas about goods were formed. ${ }^{3}$ Yet all of these interpretations link consumption with the construction of material culture, defined broadly to encompass both the built environment and material artefacts.

Within this growing corpus of research, relatively little attention has been paid to the aristocracy as consumers or the country house as a site of consumption. Of course, an enormous amount has been written about the country house. One well-established line of enquiry has taken an economic-based view, focusing on the management of the estate, balance sheet of income and expenditure, and the use of marriage settlements, inheritance, mortgages and credit to sustain elite estates. ${ }^{4}$ Another has focused on the country house as a vehicle of the social and political ambition of the English aristocracy and gentry. As Stone and Stone have argued, it was the embodiment of elite status and power: an expression of conspicuous consumption intended to communicate clear messages of social order and political power. ${ }^{5}$ The aristocracy thus spent huge sums building and decorating their houses and landscaping their grounds: $£ 78,000$ was spent on rebuilding Castle Howard, over $£ 90,000$ on Holkham Hall and $£ 100,000$ on Audley End. ${ }^{6}$ The economic capital of a great house was underlined by its symbolic capital since both house and garden represented and communicated the taste and discernment of the owner. Indeed, Corfield has argued that 'power was resynthesized into active terms, of acquisition, production, and display, rather than of inheritance, formal title, and ancient lineage.' ${ }^{7}$ Thus, money was spent not simply on building, but on rebuilding houses to keep

\footnotetext{
1 This research is linked to the project 'Consumption and the Country House', funded by the AHRC: $\mathrm{AH} / \mathrm{HoOs365/1}$. I would like to thank two anonymous referees for their helpful comments on an earlier draft of this paper.

${ }^{2}$ Berg, Luxury and Pleasure, p.5.

${ }^{3}$ See, Brewer and Porter Consumption and the World of Goods; Berg and Clifford, Consumers and Luxury; Vickery, Gentleman's Daughter; Smith, Consumption and the Making of Respectability; Borsay, English Urban Renaissance; Stobart, Hann and Morgan, Spaces of Consumption.

${ }^{4}$ See, Canadine, Lords and Landlords; Beckett, The Aristocracy in England; Habbakuk, Marriage, Debt, and the Estates System.

${ }^{5}$ Stone and Stone, An Open Elite?, pp.12-14. See also, Veblen, Theory of the Leisure Class (1912).

${ }^{6}$ Black, Subject for Taste, p.45.

${ }^{7}$ Corfield, 'Class by name and number', pp.129-30
} 
them up-to-date; on decorating and furnishing them to create fashionable and tasteful interiors, and on landscaping and re-landscaping gardens and parks to reflect prevailing fashion. ${ }^{8}$

Viewing the great house as the embodiment of social and cultural capital places emphasis on outcomes and often overlooks the processes of consumption and the systems of supply which met the needs and wants of the elite. Indeed, much of the historiography of elite consumption is skewed towards analyses which focus on material artefacts themselves as 'art', on the aristocracy as patrons of artists, architects and landscape gardeners or as connoisseurs and collectors. ${ }^{9}$ More recently, there has been growing interest in the consumption of luxury or splendour, with much attention focusing on jewellery, silverware and clothing. Here, the emphasis is on the body and the individual or on a particular elite group, such as London's beau monde. ${ }^{10}$ In many of these studies, elite consumers are largely divorced from their country houses. As a consequence, we know relatively little about the full breadth of the elite's changing material culture; the mundane consumption practices through which their ambitions and tastes were brought to fruition, or the everyday systems of supply that serviced their demands - the work of Peck on seventeenth-century and, more especially, Vickery on eighteenth-century elites being notable exceptions. ${ }^{11}$ Two things make this neglect all the more striking: first is the emphasis placed on such issues by historians of the consumption practices of the middling sorts, ${ }^{12}$ and second is the importance accorded to the elite as the engine of consumer transformation in the eighteenth century. According to McKendrick, they set the standards and fashions which others sought to follow, and thus stimulated a consumer revolution driven by emulation. ${ }^{13}$ But the recently burgeoning literature on consumption and material culture has made little attempt to establish how the gentry and aristocracy fitted into wider patterns of behaviour in terms of both the acquisition and ownership of goods. Were they part of a wider transition towards fashion-driven consumption - perhaps even the drivers of emulative consumption as Veblen and McKendrick would have us believe? Or did they seek to follow rather different consumption priorities to mark their social distinction? ${ }^{14}$

This paper forms an attempt to address these issues. In it, I draw on the bills and receipts of the Leigh family of Stoneleigh Abbey in Warwickshire to recreate the processes through which the

\footnotetext{
${ }^{8}$ Christie, British Country House.

${ }^{9}$ See, for example, Guilding, Marble Mania: Sculpture; Harris, Robert Adam and Kedleston; Wilson, William Kent; Beard, Georgian Craftsmen.

${ }^{10}$ Pointon, 'Jewellery in eighteenth-century England'; Clifford, 'Precious metalwork'; Peck, Consuming Splendor, especially chapters 2 and 3; Grieg, 'Leading the fashion'.

${ }^{11}$ Peck, Consuming Splendor; Vickery, Gentleman's Daughter. See also Williams, 'The noble household'.

${ }^{12}$ See, for example, Weatherill, Consumer Behaviour; Stobart, Hann and Morgan, Spaces of Consumption; Berry, 'Polite consumption'; Cox, The Complete Tradesman.

${ }^{13}$ McKendrick, 'Consumer revolution'. This argument builds on the work of Veblen, Theory of the Leisure Class.

${ }^{14}$ See Bourdieu, Distinction.
} 
material culture of the family home was constructed. ${ }^{15}$ A sample of thirteen years was taken to give a picture of (changing) consumption patterns across the eighteenth century. The sampled years were: $1710-12,1736,1738,1750-52,1765-66,1768,1789-90$ - chosen to capture something of the spending of three generations of the Leigh family: Edward (who inherited in 1710), Thomas (1738) and Edward (1749, but arriving at his majority only in 1764). This produced a total of 628 bills for a huge range of goods and services (from nails to necklaces and from candles to coaches) with values ranging from a few shillings to over $£_{1,100 .}{ }^{16}$ My concern is not with tracing the agency of individual members of the family or particular heads of the household. Whilst these are clearly important themes which merit much fuller exploration than they have received in the past, ${ }^{17}$ I want to focus here on the systems of supply and, more especially, the complex consumption patterns of this elite family.

As a starting point, I identify and map those supplying the Leighs with goods and services, and explore the relative importance of local and metropolitan tradesmen in furnishing the country house and in feeding and clothing its occupants. ${ }^{18}$ Building on this, I explore the nature of the relationship between these tradesmen and the Leigh family: were there favoured suppliers or did the Leighs shop around for goods? Moving on from the practicalities of supply, the heart of the paper lies in an

${ }_{15}$ The bills and receipts include some expenditure on the estate (for example, for fencing, shoeing horses and repairing cottages). In order to focus on the material culture of the house, these bills have been excluded from the sample analysed here.

${ }^{16}$ In the analysis that follows, no adjustment has been made for temporal variations in prices. Overton, 'Prices from inventories', pp,139-41, suggests a drop in the (second-hand) value of many inventoried goods through the late seventeenth and early eighteenth centuries. Schumpter-Gilroy Price Index indicates that the prices of new consumer goods (excluding cereals) were broadly stable over the study period as a whole (see Mitchell, Abstract of British Statistics, pp.468-9). Internal evidence from the bills themselves is difficult to assess, given variations in supplier and location, but there is little to suggest significant changes in the cost of goods purchased by the Leighs.

${ }_{17}$ Most analyses focus on individual consumers rather than the changing patterns of consumption from one generation to the next: see Vickery, Gentleman's Daughter; Berry, 'Prudent Luxury'; Williams, 'The noble household'; Grieg, 'Leading the fashion'. Inter-generational shifts and individual agency form key themes in my current AHRC-funded project, 'Consumption and the Country House'.

${ }_{18}$ This mapping exercise is quite straightforward when the bill includes an address as well as the name of the supplier. When no address was recorded, it was necessary to try to identify the trader from other sources via nominal record linkaging. This was done by searching trade directories, calendars of wills, poll books, freemen rolls, newspaper advertisements and collections of trade ephemera. Only suppliers who could be identified with certainty (correct forename and surname, appropriate location and trade, and feasible dates) were included - a process which inevitably means that a significant number of omissions. It is impossible to know the extent to which this might effect the picture created, but it probably results in an over emphasis of London suppliers (see below) and an underplaying of the breadth of the supply network rather than a fundamental distortion of the geography of the supply network. 
exploration of the ways in which the consumption practices of this aristocratic family mesh with theorisations of the changing nature of consumption in the eighteenth century. In particular I focus on the extent to which the Leighs engaged with a so-called new material culture - one that was increasingly driven by the exigencies of fashion and which spread to encompass ever wider sections of society. ${ }^{19}$ In doing so, I contend that the consumption practices of the eighteenth-century provincial elite were not simply driven by fashion, either for its own sake or as a means by which they might be distinguished from an increasingly assertive middling sort. Whilst taste and fashion were important, they were tempered by other, more 'dynastic' forms of consumption which emphasised traditional concerns of the elite: patronage, display and heritance. Situating this in the broader historiography of consumption, I argue that it not only places further question-marks against the validity of emulative models of consumption (already challenged by those looking at the consumption of middling sorts), but also suggests that the elite continued to draw on values systems and status markers unavailable to the middling sorts.

The Leighs were raised to the peerage in 1643, but were never amongst the first flight of the aristocracy: they never held high office and only in the nineteenth century did they begin to marry into the upper reaches of the nobility. In the eighteenth century, they were essentially county magnates: wealthy, but not extravagantly so. Their annual income from land amounted to $£ 6,975$ $10 s 6 d$ in 1749 and, a year later, a general account of the personal estate of the fourth Lord Leigh totalled a little over $£ 5$,000 including livestock and crops. ${ }^{20}$ By and large, they appear to have lived within these means for much of the eighteenth century; even the rebuilding of the Abbey appears to have been undertaken at a cost of little more than $£ 3,330$. As the name suggests, Stoneleigh Abbey was originally built Cistercians. Dissolved as part of the reformation, the abbey and estate were acquired by Sir Thomas Leigh in 1562. What followed was a long and intermittent process of converting the abbey into a country house and, in the eighteenth century, modernising the design by the addition of a grandiose baroque west range. This was largely completed by 1725 , but it was not fully occupied until around $1740 .{ }^{21}$ Where, then, did the Leighs go to find professionals and tradesmen to decorate and furnish their house, supply textiles for clothing, food for their table and so on?

The basic geography of supply appears, at first glance, to have been relatively straight-forward. London dominated both in terms of the number of suppliers and the overall amount spent there

\footnotetext{
${ }^{19}$ See McKendrick, 'Consumer revolution'; McCracken, Culture and Consumption, pp.16-21; de Vries, Industrious Revolution.

${ }^{20}$ MacDonald, 'The Leigh family', p.149.

${ }^{21}$ Morris, 'From monastery to country house', pp.15-61; Gomme, 'Abbey into palace', pp.82-115.
} 
(Table 1). Indeed, in monetary terms, the capital accounted for three-times as much spending as all other places put together. To an extent, this is a reflection of the relative ease of identifying London tradesmen amongst the records: many small-scale local suppliers are far more difficult to definitely identify or to confidently attribute to a particular place. Yet it also confirms the general impression of elite families either buying many of their goods in person whilst in town for the season or ordering them directly from London shops who were known (by experience or reputation) to be able to supply high quality or fashionable items. ${ }^{22}$ Of the other places to which the Leighs looked for supplies, the two which stand out are Coventry and Warwick. The former lies slightly closer to Stoneleigh and accounted for about one-fifth of the bills sampled, although many of these were for small amounts. For example, in 1738 the Coventry china dealer John Taylor presented three bills totalling $£^{4} 19 \mathrm{~s} 5 \frac{1}{2} \mathrm{~d}$, whilst, fifty years later, purchases of skins and gloves from Stephen Pollard amounted to just 16 shillings. ${ }^{23}$ All together, Coventry traders commanded less than 10 percent of the total spent by the Leighs. In contrast, Warwick retailers appear to have been patronised less often, but for larger purchases - a pattern which links closely to Warwick's position as a centre for high quality craftsmen and builders; a point to which we shall return later. Beyond these towns, spending was limited to a handful of purchases often made as part of leisure trips (Cheltenham) or by a younger member of the family resident elsewhere (Oxford).

There was thus a remarkable concentration of spending in just three places. Moreover, whilst the relative importance of each town varied from one decade to the next, there was no marked overall trend towards concentration or diversification in terms of the geography of supply. Bills from London retailers comprise a slightly higher proportion in the second half of the eighteenth century than they do in the first, but the difference is probably a reflection of their growing tendency to use bill headings and thus to be more readily identifiable rather than any fundamental shift in the spending patterns of the Leigh family.

Table 1 about here

If we consider the kind of goods and services being bought in these three towns, some striking patterns begin to emerge. London was, unsurprisingly, the chief source for luxury goods. Most of the $£ 4,642$ recorded as being spent on silverware, art and books in the thirteen sample years was laid out on items from London shops. This included $£ 489$ s 1 d for a silver 'thread tea vase' from Robert Makepeace on Terle Street; $£ 26$ s for 'two large India Mandareene Figures' from Charles Vere on

\footnotetext{
22 Vickery, Gentleman's Daughter, pp.164-183; Stobart, Hann and Morgan, Spaces of Consumption, pp.54-5; Peck, Consuming Splendor, pp.25-72.

23 Shakespeare Birthplace Trust (SBT), DR18/5/2111, DR18/5/2058, DR18/5/2191, DR18/5/5845, DR18/5/5860a.
} 
Fleet Street; 9 guineas for a pair of globes from George Adams, and $£ 105$ for a 113 volume set of the publications of L'Academie de Sciences bound in morocco leather, bought from Thomas Payne of St Martin in the Fields. ${ }^{24}$ Almost certainly, such items were only available from specialist shops in London. The same is probably true of high quality decorations and furniture. Beard suggests the London upholsterer Thomas How as the likely supplier of upholstered chairs bought around 1730,25 and the household accounts include bills from several notable London tradesmen, including the upholsterers and furniture makers John Burroughs, Thomas Burnett, and William Gomm \& Co., and the wallpaper merchants Bromwich and Leigh. These high status suppliers were often given large orders, but one-off items were also bought in this way. For example, Burrough's 1710 bill includes at least 34 chairs and hundreds of yards of textiles, whilst that of Bromwich and Leigh (1765) itemises the wallpaper supplied and hung in each room of the house. In contrast, John Pardoe sold the Leighs just three items of furniture in 1738: a mahogany dining table, a large carved and gilt framed mirror, and a mahogany voider inlaid with brass. ${ }^{26}$ These were high quality items and, although Gomm and Co., Bromwich and Leigh, and Makepeace were not in the first rank of craftsmen, their London credentials gave them extra kudos and added to the symbolic value of their goods. ${ }^{27}$

The gentry often showed a preference for buying high quality furnishings, tableware, clothing and foods in London, even if they were available in local towns. ${ }^{28}$ This suggests a hierarchy of suppliers, with more mundane items, less important in shaping the identity and status of the consumer, being sourced locally - a model which fits well with traditional notions of retail location theory. ${ }^{29}$ Whilst this dichotomy works up to a point, the consumption practices of the Leighs reveal a far more nuanced system of supply. In addition to luxury items, London was the source of many everyday commodities - things like groceries and haberdashery - that were certainly available more locally. Here again, the rationale for buying from metropolitan suppliers was partly distinction: they offered a better choice and/or higher quality. Thus, we might draw a contrast between the London draper Sarah Gunter, whose sales to the Leighs included Italian and Persian silks, and William Butler of Kenilworth whose transactions centred on supplying the servants' livery. ${ }^{30}$ Yet this contrast between metropolitan and local quality is less discernable in the bills presented by London and more local grocers: tea, coffee and chocolate were, perhaps, more likely to be ordered from London, but local suppliers, especially in Coventry, were prominent in providing the Leighs with a wide range of

\footnotetext{
24. SBT, DR18/5/5858, DR18/5/4515, DR18/5/4383, DR18/5/4482.

${ }^{25}$ Beard, Upholsterers and Interior Furnishing, p. 184.

${ }^{26} \mathrm{SBT}, \mathrm{DR} 18 / 5 / 1808, \mathrm{DR} 18 / 5 / 4402, \mathrm{DR} 18 / 5 / 2216$, DR18/5/2218.

27 A communion table made in 1765 by Gomm and Co. for the Leighs is now held at the Victorian and Albert

Museum - see Gomme, 'Abbey to palace’, p.97.

${ }^{28}$ Vickery, Gentleman's Daughter, p.169

${ }^{29}$ For a summary of these ideas, see Stobart, Hann and Morgan, Spaces of Consumption, pp.38-49.

${ }^{30} \mathrm{SBT}, \mathrm{DR} 18 / 5 / 1858, \mathrm{DR} 18 / 5 / 2105, \mathrm{DR} 18 / 5 / 5657, \mathrm{DR} 18 / 5 / 5867$
} 
foreign foods. In the 1730s, John Hollyer was supplying brandy, Madeira and other imported wines and, a generation later, Hugh Jones sold the Leighs tea, coffee and spices. ${ }^{31}$ How might we best understand this seemingly overlapping system of supply? The kudos of London was important, and it is clear that some metropolitan retailers were able to offer goods of a better quality or at keener prices than those available locally. Thomas Thompson, for instance, invoiced the Leighs in 1768 for a hamper containing best plain chocolate, fine green tea; fine souchong tea; fine green souchong; fine congou, and best turkey coffee..$^{32}$ Multi-purpose trips may also have been significant, with purchases of everyday items being made whilst ostensibly shopping for higher order goods. More important, though, were purchases made in London whilst the family were visiting for the season or - as appears to have been the case for Miss Caroline Leigh in the 1750 s - more permanently resident there. In this sense, London retailers became local, at least for the season. This important point has rarely been discussed in relation to elite consumption. ${ }^{33}$ Yet the upper gentry and aristocracy were highly mobile geographically: their 'everyday' spending thus had a temporally contingent impact on local suppliers. ${ }^{34}$

Whilst London reached down the hierarchy of retail circuits and operated as a point of supply for everyday as well as luxury goods, retailers in Coventry and Warwick appear to have been unable to compete with their London rivals at the upper ends of the market. Many of the goods that were locally supplied were relatively low cost and mundane items, most notably groceries and hardware, including candles, brushes, ironmongery, pans and barrels. Add to this the numerous sales of bricks, tiles, nails, saddlery and timber, and the plumbing, glazing, blacksmithing, bricklaying and masonry work carried out at the Abbey, and the local network of basic supply becomes very intense. Added to this was the dense web of suppliers who provided the house with perishable foods, often appearing in the bills and receipts grouped under the heading 'household accounts'. That for 5 August 1738 included, amongst other things: peas, besoms, cherries (red and black), turnips, cheese, raspberries, cider, lemons, oranges, newspapers, vinegar, greens, strawberries, beans, carrots, cucumbers, capers, crabs, oil, wooden dishes, fish, eggs, whiting, ducks and asparagus. ${ }^{35}$ This long list, and the total value of $£ 123 \mathrm{~s} \mathrm{1d}$, clearly reflected the combined efforts of a large number of local producers and suppliers, including some on the estate itself. Such supplies were vital in servicing the daily needs of

\footnotetext{
${ }^{31} \mathrm{SBT}, \mathrm{DR} 18 / 5 / 2067, \mathrm{DR} 18 / 5 / 4214$.

${ }^{32}$ SBT, DR 18/5/4692.

${ }^{33}$ The gentry families studied by Vickery, Gentleman's Daughter, received goods and news from London, but did not spend the season there. Much the same was true of the Baker family in County Durham: see Berry, 'Prudent luxury'.

${ }^{34}$ Something of his has been noted in reverse with some London retailers setting up shop in provincial spas for the season (see Stobart, Spend, Spend, Spend, p.105), but it needs much fuller investigation in terms of the metropolitan and provincial retail systems more generally.

${ }^{35}$ SBT, DR 18/5/2150.
} 
the Leighs and their household. However, just as it would be a mistake to view London purely as a point of supply for luxury goods, so it would be wrong to dismiss local traders and towns as irrelevant to the construction and operation of Stoneleigh Abbey as a symbol of elite power and taste. Indeed, the design and construction of the grand west range was the work of the Warwick man, Francis Smith: then the leading architect in the Midlands. Originally commissioned in 1714, Smith first produced a design for re-facing the west wing of the house and later a plan for the new west range. ${ }^{36}$ To carry out the work, it is likely that he employed the same local craftsmen that he is known to have used elsewhere, including the joiner George Eborall and the carver Benjamin King, both of Warwick; the Birmingham locksmith John Wilkes, and John Wright a stuccoist from Worcester. After Smith's death, the interior decoration of the new range was entrusted to another Warwick-based architect, Timothy Lightoler, and much of the building work was carried out by William Hiorn, also of Warwick. His 1764 bill itemises a number of ornate marble chimney pieces. ${ }^{37}$ Perhaps with a desire for better quality workmanship or the kudos of metropolitan associations, ${ }^{38}$ subsequent and more ornate chimney pieces were made by the London partnership of Bastard and Fox. And yet Warwick craftsmen continued to play a role in fashioning the fabric of the Abbey: in 1763 Robert Moore was paid $£ 75$ 13s 10d for plasterwork and in 1789 Richard Bevan presented a bill for painting, varnishing and gilding which amounted to $£_{299}^{5}$ s $10 d .{ }^{39}$

Coventry tradesmen were missing from this structural and decorative work, but the city's retailers were still important in supplying a range of luxury items. In the 1760 s, the plantsman Jonathan Whittingham was the Leigh's chief source of trees, plants and seeds for both the kitchen and ornamental gardens. Around the same time, William Allen was supplying china and earthenware, Abel Gravenor was selling wines and spirits, and Lilley Smith a range of teas and coffees..$^{40}$ Indeed, the quality of goods available from Smith could rival many London shops, including five types of tea: green, bohea, hyson, congou and souchong. ${ }^{41}$ Much the same could be said of certain drapers: Robert Hughes, for example, supplied a wide variety of luxury textiles, including 'rich black velvet', 'fine holland', 'rich white favours' and 'fine grey sagathy'. ${ }^{42}$ The availability of such goods in provincial towns might point towards a democratisation of luxury, but evidence from shopkeepers' inventories indicates that this was not a new development in the eighteenth century. ${ }^{43}$ More remarkable than the

\footnotetext{
${ }^{36}$ Gomme, 'Abbey to palace', pp.82-3.

${ }^{37}$ SBT, DR 18/5/4192. See also Beard, Decorative Plasterwork, pp.57-8.

${ }^{38}$ Gomme, 'Abbey to palace', p.99.

${ }^{39}$ SBT, DR $18 / 5 / 4070$, DR 18/5/5864.

40 SBT, DR18/5/4171, DR18/5/4140, DR18/5/4177.

${ }^{41}$ For a fuller discussion of the spread and practices of provincial grocers and particularly tea dealers, see Mui and Mui, Shops and Shopkeeping, pp.29-48, 221-248.

${ }^{42}$ SBT, DR 18/5/2129, DR18/5/2210.

${ }^{43}$ See, for example, Styles, Dress of the People, pp.135-66; Stobart, Hann and Morgan, Spaces of Consumption, pp.128-9.
} 
availability of such goods in provincial shops is the fact that the Leighs clearly saw these local retailers as perfectly capable of meeting many of their needs. ${ }^{44}$ This was facilitated by the willingness of shopkeepers to acquire for the Leighs certain goods which they did not necessarily have in stock and even to bend their usual practice to accommodate what were clearly valued customers. Thus we see Elizabeth Taylor writing in March 1764 that she was:

'... very sorry to find the Glasses are not such as you approve. I thought the mettal to be very good, theyre not being liked will be a considerable disadvantage to me, as they were order'd on purpose for his Lordship; but if you do not intend to keep thme after 12 instant, hope you will send them back by the miller as I have no objection to hireing them for the time, tho' its what I do not very commonly do, ${ }^{45}$

That Taylor was content to have the goods returned is no great surprise; that she was prepared to hire them out after they had been rejected is perhaps more striking, although it might be seen as a means of recouping some of her expense.

\section{II}

The pattern of supply was far from a being simple dichotomy of local-everyday and metropolitanluxury purchases, with choices being made across a range of provincial and London retailers. Evidence from the middling sort and urban gentry suggests that many consumers established longterm relationships with particular suppliers, sometimes referring to them as 'my draper' or 'my bookseller'. Such stable relationships were important both to shopkeepers and their customers. The former benefited from a regular stream of orders, whilst the latter were assured of attentive service and, crucially, reliable information about and supplies of consumer goods. ${ }^{46}$ Less clear is the extent to which the same might be true of wealthier consumers who enjoyed greater economic power and the ability to draw supplies from a much larger area, although Berry notes the long-standing relationship between the Baker family and certain London shops. ${ }^{47}$ With a sample period stretching over 80 years, it is inevitable that there would be considerable turnover in the people supplying Stoneleigh Abbey, no matter how loyal the family were to particular suppliers. This is reflected in the sheer number of retailers patronised by the Leighs. In the years sampled, over 420 tradesmen and women presented bills, including 16 different china and glass sellers; 25 booksellers and stationers; 62 ironmongers, chandlers, coopers and smiths, and 85 drapers, haberdashers, dressmakers and tailors. But there is also evidence of considerable continuity of supply - at least as

\footnotetext{
${ }^{44}$ On the wide availability of textiles and clothing in the provinces, see: Styles, Dress of the People, pp.135-52.

${ }^{45}$ SBT Dr18/5/4122.

${ }^{46}$ Cox, Complete Tradesman, pp.135-9; Stobart, Hann and Morgan, Spaces of Consumption, p.156; Berry, 'Prudent luxury’; Blondé and Van Damme, 'Retail growth and consumer changes’.

${ }^{47}$ Berry, 'Prudent luxury', pp.147-9.
} 
far as some retailers were concerned. Sarah Gunter made dresses and sold textiles and haberdashery to the Leighs for at least twenty-five years in the early eighteenth century and William Neale supplied ironmongery for a similar period. William Mander carried out carpentry at Stoneleigh from the 1760 s into the 1780 s, during which time Charles Haynes was making house calls and supplying medicines, and William Butler was providing drapery and tailoring services from his Kenilworth shop.

Within this group of long-standing contacts were some who clearly enjoyed especially favoured status, apparently operating as the preferred supplier of particular goods. Butler might fall into this category in terms of his provision of a range of livery for servants at Stoneleigh Abbey. More prominent were some of the London retailers. When the house was being refurbished in the mid 1760 s in preparation for, and subsequent to, the coming of age of Edward, the fifth Lord Leigh, there was a burst of spending. ${ }^{48}$ In excess of $£ 300$ of table linen was ordered from the London partnership Jordan, Heyland and Biggar over a four year period, during which time they dominated the Leigh's purchasing of such wares. Similarly, Edward Nairne was the main source for a range of scientific equipment, whilst Thomas Gilpin enjoyed the lion's share of the Leigh's considerable spending on silverware and jewellery from the 1730 s through to the 1760 s. Yet no single retailer was ever a monopoly supplier to the Leighs, suggesting either that they were unable to find all the goods they needed from a single shop or that they (or their agent) actively shopped around to secure the best price, quality or choice possible. We have direct evidence of Sir John Morduant's servant shopping in this way in London. He wrote to his master detailing prices and qualities of a range of groceries he had been sent to buy. ${ }_{49}$ For the Leighs, the evidence is less direct, but is suggestive nonetheless. For everyday goods, the family were often buying from several different suppliers at a given time. Thus, in 1768, groceries were purchased from five different shops: Blackiston, Myles \& Co. on the Strand; Thomas Edwards at the Fig Tree in Brewers Street near Golden Square; Thomas Thompson of London; Lilley Smith of Coventry, and Bartholomew Churchill, whose address is unknown. ${ }^{50}$ To an extent, this was a case of specialist sourcing - a fairly common practice when buying groceries, whereby tea and sugar might be bought from one supplier, coffee and chocolate from another, spices from a third, and so on. For the Leighs, Thompson appears to have been the main supplier of tea at this date, whilst spices came in greatest number and variety from Blackiston, Myles \& Co. However, there were two grocers supplying tea and two supplying coffee, whilst dried fruit came from three different shops, and spices from four. The Leighs were spreading their custom in a manner closely resembling the middle ranking consumers who patronised the shops of Thomas Dickenson and other

\footnotetext{
${ }^{48}$ MacDonald, ‘The Leigh family’, pp.149-50.

${ }_{49}$ Warwick Record Office, CR 1368, Vol. 4/57 Morduant Family Letters. For details of such practices, see Stobart, Hann and Morgan, Spaces of Consumption, pp.151-8.

${ }^{50}$ SBT, DR18/5/4592-4716.
} 
grocers in mid-eighteenth-century Worcester. ${ }^{51}$ Some choices may have been based on quality, but all three London grocers supplied goods described as 'fine' or 'best', suggesting that other motives, such as price or personal preference, were also important. Indeed, the fact that Blakiston, Myles \& Co. were also patronised by the Baker family of County Durham suggests that provincial elites may have shared particular patterns of consumption centring on favoured retail outlets. ${ }^{52}$

Much the same practice of patronising different suppliers of the same basic range of goods for subtly different requirements can be seen for luxury goods. As part of the 1760 s refurbishment of the house, an extensive and costly library was assembled through frequent and substantial purchases, mainly from four London booksellers: James Fletcher at St Pauls, Thomas Payne at St Martin in the Fields, James Robson on New Bond Street, and Paul Valient. As the addresses suggest, these booksellers were rather different from one another and there was some specialisation of provision: Payne tended to supply histories and classic texts, some in Latin; Fletcher sold scientific and religious books, and Valient folio editions of prints. ${ }^{53}$ However, there was considerable overlap and the impression is that Lord Leigh was acquiring good quality books as and where he could. Moreover, it is clear that he did not always take the initiative when it came to choosing books. Instead, the booksellers sometimes tried to anticipate his tastes, Payne writing on one occasion that: 'I have made bold to send yr Lordp Dionysius and Juston, they are good copies but if not approved of, shall be taken again. I am so much stuffed up with Books that I am glad to send them out of my way'.54 Significantly, Payne emphasised the quality of the copies rather than that of the books themselves - it was apparently taken as read that these texts would be worthy additions to a gentleman's library.

The patronage of several booksellers - and of a number of paint and print sellers - might reflect problems of supply. If particular books or a certain type of picture were sought after, then the consumer might need to draw on the supply systems focused on a number of specialist retailers. The same was scarcely true of china and decorative glass, which was widely available and pretty commonplace even amongst the middling sort by the second half of the eighteenth century. ${ }^{.5}$ And yet the fifth Lord Leigh chose to patronise a number of china and glass sellers in the 1760 s. Some were used for specialist items - Jenkin Jones, for example, supplied a range of decorative glass in the shape of leaves - but Rachel Leggat, James Neale, William Allen and Charles Vere were all supplying large quantities of china tea or dinner services. The reasons for this dispersal of custom is unclear since the goods were all fairly plain and the quantities, whilst large, were unlikely to be beyond even provincial retailers. Even though their motives might remain obscure, it is apparent

\footnotetext{
${ }^{51}$ Stobart, Hann and Morgan, Spaces of Consumption, pp.154-5.

${ }^{52}$ Berry, 'Prudent luxury', p.148.

${ }_{53}^{53}$ See, for example, SBT, DR18/5/4440, DR18/5/4384, DR18/5/4202.

${ }_{54} \mathrm{SBT}, \mathrm{DR} 18 / 5 / 4452$.

${ }_{55}$ Weatherill, Consumer Behaviour, pp.169-88.
} 
that the Leighs were exercising choice as consumers: they were in contact with and could readily acquire goods from a large range and number of retailers, both in London and the provinces.

III

Relating the practices and outcomes of buying revealed above to wider processes and conceptions of consumption, it is possible to see the Leighs as modern consumers caught up in the changing material culture of the age. Across Europe, a new material culture characterised many homes, from the elite to the peasantry. In material terms, it involved a shift to less durable goods: china and glass replaced pewter; lighter furniture often made from imported goods replaced traditional heavier designs made from oak; wallpapers replaced tapestries; and window curtain gradually superseded bed hangings ${ }^{56}$ In economic terms, the relatively lower unit price of many of the new goods facilitated the ownership of more and/or a greater variety of items, even though their less durable nature meant that they often needed to be replaced more often. And in conceptual terms, goods became less important as stores of economic capital and more important in terms of their symbolic value - that is, as markers of status and identity. This shift is often seen in terms of a growing emphasis on the new and fashionable, and arguably involved a cultural convergence of the elite and the middling sort. ${ }^{57}$ For the elite, such a reorientation of consumption apparently came at the expense of traditional concerns of pedigree and heritance, as the meaning and definition of gentility shifted towards individual traits and behaviour. ${ }^{58}$

Many aspects of this changing material culture are apparent in the purchases recorded in the Leighs' bills and receipts. Two broad examples illustrate the point. First is the expenditure on glass and chinaware, which had already replaced pewter on the dinner and tea tables of Stoneleigh Abbey (Table 2). Whilst modest in terms of overall expenditure, the $£ 132$ spent on these goods in the thirteen sample years reflects a large amount of tableware. The bill presented by Rachel Leggat in 1764 included 14 serving dishes, 3 dozen octagonal plates, 2 dozen soup plates, 18 breakfast plates and 2 dozen engraved wine glasses. The following year, around 450 glasses of various sorts, including twisted wine glasses, champagne glasses, tumblers, ale glasses and lemonade mugs, were bought from R. Windle of London; three years after that, a further six dozen plates and two dozen

\footnotetext{
${ }^{56}$ See de Vries, Industrious Revolution; Blondé, 'Cities in decline and the dawn of a consumer society'; Overton, et al, Production and Consumption, pp.87-120.

57 There is a huge literature on the growing importance of fashion and novelty, and its impact on the middling sorts. See, for example: Berg, Luxury and Pleasure, pp.5-6, 199-246; Brewer and Porter, Consumption and the World of Goods; McKendrick, 'Consumer revolution', pp.9-20; Smith, Consumption and the Making of Respectability, pp.41-43; Vickery, Gentleman's Daughter, pp.13-37, 161-4.

${ }^{58}$ For discussion of this transition, see: Corfield, 'Class by name and number'; Heal and Holmes, Gentry in England and Wales, pp.6-19, 98-101, 178-84.
} 
soup plates were bought from James Neale. ${ }^{59}$ It is notable that none of the chinaware recorded in the accounts is described as patterned; nor, with the exception of a small set of Wedgwood dishes bought in $1790,{ }^{60}$ was any of it apparently from one of the foremost porcelain manufacturers. Nonetheless, there was clearly an ongoing process of renewing tableware rather than simply replacing broken items. That this was purchased in sets suggests sustained engagement with a new material culture emphasising fashion, but also a desire to mark distinction from middling sort consumers through the possession of tableware that facilitated large-scale and elaborate dining. ${ }^{61}$

Table 2 about here

The second example is the changing nature of the furniture being acquired from craftsmen in London. The furnishings bought from, and work carried out by, John Burroughs in 1710 were of a fairly traditional nature. The emphasis was on the quality of the cloth used for the upholstery and bed hangings, and much of the expenditure went on beds and bedding - traditionally the most valuable items of furniture in many homes. The only wood mentioned was walnut. ${ }^{62}$ By the 1730 s, most of the furniture being bought was gilded or of mahogany, and even local craftsmen were engaged in making elaborate pieces, including drop-leaf tables and sideboards for the parlour. ${ }^{63}$ Thirty years later, the furniture ordered from Gomm \& Co. was of a very different character and seems to have represented a complete refurnishing of several rooms. There were dozens of mahogany chairs, clothes presses, basin stands, shaving tables, Pembroke tables, serpentine commodes, chests of drawers, dressing tables, night tables, a set of dining tables, writing tables and a rococo communion table for the chapel. ${ }^{64}$ Moreover, each piece or set was described in a level of detail that laid constant emphasis on the quality of the workmanship: it was not simply the wood that mattered, but also the design. In the same year, there appears the bill from Bromwich and Leigh for papering the entire house. What is telling here is not simply the act of papering the walls, but also, as Vickery notes, the way in which the style and colour of the papers varied from room to room, reflecting the different level of public access to and character of the room, and the nature of the decorative stucco work found therein. ${ }^{55}$

\footnotetext{
${ }^{59}$ SBT, DR 18/5/4199, DR18/5/4320, DR 18/5/4678.

${ }^{60} \mathrm{SBT}, \mathrm{DR} 18 / 5 / 5900$.

${ }^{61}$ See various contributions to Symonds, Table Settings, especially those by Unwin and Banham.

${ }^{62}$ SBT, DR18/5/1808. See Overton, et al, Production and Consumption, pp.81, 91, 110, on the identification of wood types in probate inventories.

${ }^{63} \mathrm{SBT}, \mathrm{DR} 18 / 5 / 1816$.

${ }^{64} \mathrm{SBT}, \mathrm{DR} 18 / 5 / 4408$.

${ }^{65}$ SBT, DR 18/5/4402. Vickery, “Neat and not too showey”, pp.201-222
} 
As Grieg describes for members of the Beau Monde, the Leighs valued fashion not merely in terms of what was modish, but more importantly in a way that connoted 'rank, state or dignity'. In this sense, fashion was exclusive rather than inclusive: it distinguished the elite (or, in Grieg's analysis a small subsection of the elite) from other consumers and thus insulated them against the democratisation of consumption. ${ }^{66}$ Yet their attempts to make Stoneleigh Abbey a fashionable place did not always run in a smooth linear progression: the pace of change slowed markedly, for example, following the early death of the fourth Lord Leigh in 1749 and the consequent running of the estate by his rather cautious widow. Conversely, it rapidly gathered pace around the coming of age of the fifth Lord Leigh in 1764 at which time the agent, Samuel Butler wrote to the London cabinet maker Thomas Burnett that 'our house is now in greater confusion than ever ... we are making great alterations to the middle part of the House' ${ }^{67}$ Also cutting across any seamless transition to the values of this new material culture was the sometimes parallel and sometimes conflicting priority of marking and redefining aristocratic status through patronage, conspicuous consumption and heritance. This conflict of consumer models has been noted in eighteenth-century Antwerp by Blondé, but remains under-explored in the English context. ${ }^{68}$ Here, the general understanding that traditional modes of consumption were replaced for all levels of society arises primarily because conceptualisations of changing consumption regimes view elite consumers as the driving force in a broader social transformation. This is seen in the social/cultural emulation suggested by Veblen and McKendrick, but also in Simmel's notion of trickle-down. It even fits Grieg's reading of fashion and the Beau Monde: this was a powerful group, she argues, because they were by definition fashionable.69 For these models to work, the elite must, prima facie, have been at the forefront of the move to a new material culture and the lionising of fashion as novelty - an assumption that is seldom tested in empirical studies which principally focus on social groups from the gentry down. But even a cursory examination of the consumption practices of the Leighs reveals very different priorities.

Patronage was a traditional prop to aristocratic power and took many forms including local philanthropy, the placement of familial or social dependents, and support offered to artistic, scientific or cultural endeavour. The Leighs were certainly active in all these fields. They gave to charitable causes both in Warwickshire and London, making donations to the girls' school of industry in Kenilworth, subscribing to the Westminster Hospital and to a charity for decayed musicians. ${ }^{70}$ They

\footnotetext{
${ }^{66}$ Grieg, 'Leading the fashion', p.308. She traces this definition of fashion to Daniel Fenning's Royal English Dictionary (London, 1762).

${ }^{67}$ SBT, DR18/17/27/96. See also MacDonald, 'The Leigh family', p.149.

${ }^{68}$ Blondé, 'Conflicting consumption models', pp.71-4.

${ }^{69}$ Veblen, Theory of the Leisure Class; McKendrick, 'The consumer revolution'; Simmel, On Individuality; Grieg, 'Leading the fashion', pp.296-8.

${ }^{70} \mathrm{SBT}, \mathrm{DR} 18 / 5 / 5850, \mathrm{DR} 18 / 5 / 4465$, DR18/5/4483a.
} 
also sponsored the horse races in Warwick and musical concerts in Coventry. ${ }^{71}$ Less formally, musicians from Warwick and Coventry were paid for their part in the birthday celebrations for the coming of age of the fifth Lord in March 1764 when generous payments were also made to the bell ringers of St Mary's and St Nicholas in Warwick (10 and 6 guineas respectively), the three principal Coventry churches (9 guineas), Stoneleigh (5 guineas), Kenilworth (4 guineas), and twelve nearby villages (a total of 15 guineas). ${ }^{72}$ On a more practical level, the Leighs also patronised a large number of skilled craftsmen, both locally and in London.

One outcome of this patronage was, of course, a wealth of material artefacts. Many of these were luxury goods aimed at marking elite status through conspicuous consumption. One aspect of this was the employment of arguably useful, but essentially decorative servants. In this respect the liveried footmen and grooms were especially important since they were by far the most visible of the large entourage of servants employed in the country house. As was common, the Leighs went to some trouble and expense to dress their liveried servants in highly coloured suits. One bill from William Butler, for example, details the making of ' 4 blue kersey cloth great coats with scarlet cloth cuffs \& capes \& trimmings' and ' 4 green hair shag frocks, scarlet cloth waistcoats \& trimmings'.73 Another very public expression of status was the private coach - again an aspect of conspicuous consumption in which the Leighs took great care and expense, and one underpinned by the high cost of horses and servants. ${ }^{74} \mathrm{~A}$ bill paid in 1765 detailed the making of a new coach with 'neat ornamentl mouldings, painted with a glaz'd ruby colour, and the arms and dignity in very large mantles, and all the framework gilt, and the roof, back and sides japan'd'. ${ }^{75}$ The total cost of $£ 130$ reflected the workmanship and the very public statement that such a coach would make - essential in signalling the standing of family both in local and metropolitan settings. Indeed, it was the pars pro toto of an elite lifestyle, merging old repertoires of status consumption with newer concerns for fashionability ${ }^{76}$ It is therefore telling that, along with detailed instructions about colours and fabrics, careful mention was made of painting the Leigh family arms on the coach.

The most striking and certainly the most visible form of such ostentatious consumption was, of course, the country house itself. The construction of the new west range was fairly modest in

\footnotetext{
${ }^{71} \mathrm{SBT}, \mathrm{DR} 18 / 5 / 5856, \mathrm{DR} 18 / 5 / 5860$.

72 SBT, DR $18 / 5 / 4124$.

${ }^{73} \mathrm{SBT}, \mathrm{DR} 18 / 5 / 5842$.

${ }^{74}$ Blondé, 'Conflicting consumption models', pp.62-3.

${ }^{75} \mathrm{SBT}, \mathrm{DR} 18 / 5 / 4350$.

76 Burke, Historical Anthropology, p.139. Vickery, Behind Closed Doors, p.124, draws an analogy between the eighteenth-century coaches and the present-day helicopter. Whilst the numerous advertisements for used coaches and carriages found in provincial newspapers from the 1740 s onwards might question the exclusivity of the coach, it is clear that a substantial and fashionable coach was a key status symbol. See Stobart, 'Clothes, cabinets and carriages', pp.232, 236-7.
} 
comparison to developments elsewhere in the country both in terms of scale and cost; but it still comprised a strong statement of status and power, drawing on the skills of a series of Warwickbased architects of regional if not national renown (see above). The main front is more powerful than graceful, and was some distance from the cutting edge of country house design; yet its scope and grandeur allowed Stoneleigh Abbey to stand amongst the grandest houses in Warwickshire. Linked to this was the nature of the interior decoration upon which considerable expense was lavished. The overall effect was one of richness and grandeur - a conspicuous display of the economic, social and cultural status of the owners. ${ }^{77}$ Yet, although it resonated with messages of power, such decoration might be seen as part of the shift to a new system of symbolising status through distinction. The fine stucco work in the chapel and hall was again a little behind the fashion, but contained complex imagery which, of course, spoke most clearly to those with knowledge of the classical mythology and religious symbolism portrayed..$^{78}$ The display of fashionable good taste was also apparent in the growing use of elegant mahogany furniture and coloured wallpapers to furnish the rooms at Stoneleigh Abbey, and in the selection of artwork which to adorn the walls and shelves. This included old masters such as Rembrandt, fashionable prints by Hogarth, and marble busts and porcelain figurines - a typical range of goods acquired on or inspired by the grand tour. ${ }^{79}$

Taste and knowledge - and thus distinction - were also acquired from and expressed through reading, making an extensive and well-chosen library both a source and statement of social and cultural distinction. Stone and Stone have noted that, by the turn of the nineteenth century, a library was 'an appendage which no man of rank or fortune can now be without, if he possesses or wishes to be thought to possess taste or genius'. But such imperatives were clearly established a generation or two earlier. ${ }^{80}$ At Stoneleigh, around $£ 1,700$ was laid out on books between 1763 and 1766, including the classics, natural history, law, bibles and religious treatises, scientific and medical books, dictionaries, county histories and antiquarian studies. The speed with which such a wide ranging and high quality library was assembled was a tribute to the fifth Lord Leigh's good connections at Oxford and with London booksellers, and his willingness to spend large amounts of money to acquire a library that reflected and proclaimed his status as a man of learning, as well as providing a resource through which to refine his learning and polish his language for 'polite conversation in the age of the virtuosi'. ${ }^{81}$ Just as telling is the detail given about binding these volumes in a manner

\footnotetext{
${ }^{77}$ Wilson and Mackley, Building the Country House, p.240 explicitly read the country house in this way. Similar perspectives are implicit in Christie, British Country House, pp.30-48, and Black, Subject for Taste, pp.45-6.

${ }^{78}$ For a full discussion of these, see Gomme, 'Abbey to palace', pp.105-115. See Christie, British Country House, pp.179-231 for the significance of artwork, the ways in which it was displayed, and Wilson and Mackley, Building the Country House, pp.47-109 for the importance of the Grand Tour.

${ }^{79}$ SBT, DR 18/5/4490, DR 18/5/4069, DR 18/5/4542.

${ }^{80}$ Stone and Stone, An Open Elite, p.221. See also Brewer, Pleasures of the Imagination, pp.167-197.

${ }^{81}$ Reid, 'Proto-bibliophiles', p.34.
} 
which would make them an ornament to the aristocratic library. Thus, for example, we see in a bill from James Robson: 82

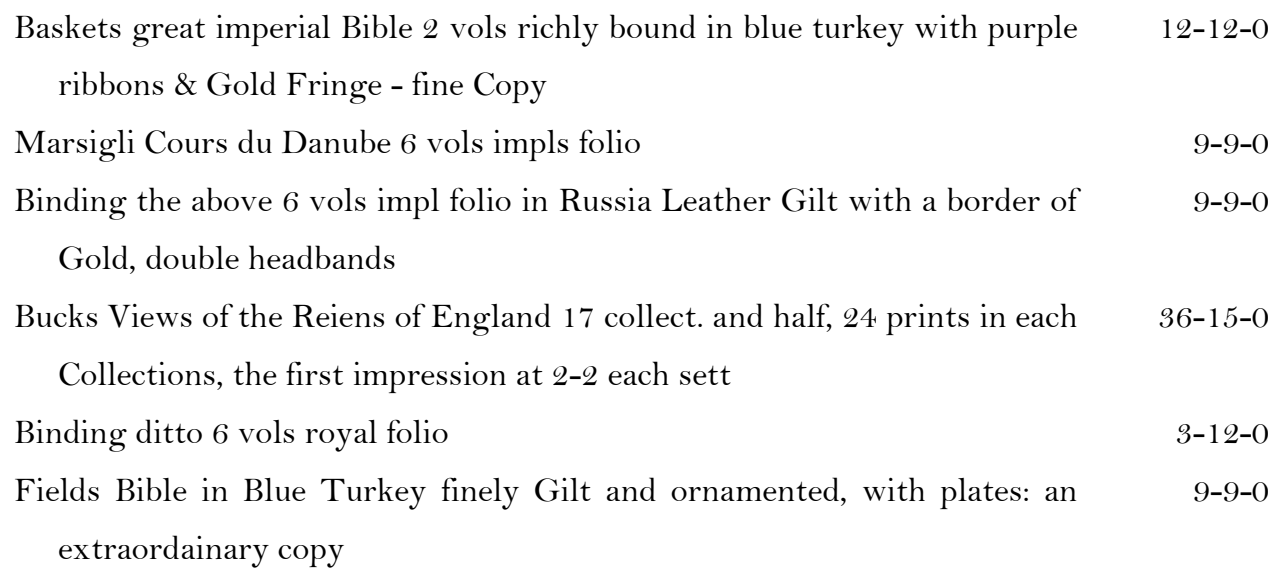

Similar attention was given to the appearance as well as the functioning of some of the scientific instruments purchased by Lord Leigh in the 1760s: the pair of 28-inch globes supplied by Edward Nairne in 1764 having silvered meridians, 'neat mahogany frames' and clawed feet. ${ }^{83}$ In such pieces and in the books that lined the shelves, taste and learning was communicated through outward appearance as well as internal content and meanings.

Finally, despite claims that the importance of inheritance, formal title, and ancient lineage was waning in the eighteenth century, ${ }^{84}$ the Leighs were assiduous in impressing their arms on a wide range of items; thus proclaiming their status and heritance. As well as the coach, they paid for the painting of escutcheons in 1738 and almost invariably had their silverware engraved appropriately. Indeed, every bill from the London silversmith Thomas Gilpin records the charge for engraving crests on the goods that he was supplying. ${ }^{85}$ As Berg suggests, this stamping of title onto material objects changed anonymous, if splendid, goods into 'signifiers of family and memory', but it also rendered them symbols of heritance and power. ${ }^{86}$ The four dozen plates and sixteen dishes supplied by Gilpin in 1750 at a cost of $£ 4896$ s $7 \mathrm{~d}$ constituted a significant financial investment and a statement of wealth. ${ }^{87}$ Together, these would have formed an impressive display at the dinner table, especially when grouped for Le service Francaise and accompanied by some of the many candlesticks, waiters, bread baskets, sauce boats and spoons also purchased from Gilpin. When these items were engraved with the family arms, their visual impact was reinforced by messages of status and heritance: they spoke volumes of the Leigh's established position in society. Engraving thus

\footnotetext{
${ }^{82}$ SBT, DR 18/5/4529.

${ }^{83}$ SBT, DR 18/5/4205.

${ }^{84}$ Corfield, 'Class by name and number', pp.129-30.

${ }^{85} \mathrm{SBT}, \mathrm{DR} 18 / 5 / 2178, \mathrm{DR} 18 / 5 / 2100, \mathrm{DR} 18 / 5 / 4251$.

${ }^{86}$ Berg, Luxury and Pleasure, p.242.

${ }^{87}$ SBT, DR 18/5/3121.
} 
underlined the importance of silverware to aristocratic self-image. Even with the growing emphasis on workmanship, particularly apparent in the pieces bought in the 1780 s from Robert Makepeace, the silverware purchased by the Leighs was invariably marked with the family crest. ${ }^{88}$ This very traditional form of elite material culture thus retained a central position in their purchasing patterns, domestic entertaining, and social status. It marked their distinction from the rising middling sorts in a way that drew on and reinforced established social markers as well as more 'modern' notions of fashion. The cost of silverware and fashionable workmanship marked economic and cultural capital; engraving it with the family crest signified heritance as a particular form of human and symbolic capital.

IV

The household accounts of the Leigh family provide a fascinating insight into the changing material world of the (minor) aristocracy in the eighteenth century, and cast useful light on wider practices of retailing and consumption. They reveal that the Leighs acquired many of their goods in London: not only luxury items, but also smaller and more mundane commodities - things like groceries and haberdashery that were certainly available more locally. This might be explained, in part, by the enormous reach of London retailers or by the habit of making multi-purpose shopping trips to London. However, for the Leighs, purchases made whilst in the capital for the season were more probably significant. At the same time, a wide range of goods and services were provided by local shopkeepers, craftsmen and professionals: some were everyday items, bought locally for convenience; but others were fashionable luxuries or reflected skilled workmanship. Perhaps most striking is the sheer number of shopkeepers and others supplying the Leighs who, whilst they clearly had favoured suppliers, patronised a large number of retailers, often buying a similar range from two or more shops simultaneously. These practices reflect the vibrant nature of provincial retailing in the eighteenth century, further exploding the myth of primitive provisioning in the era before department stores and multiple-shop retailing. In part this vibrancy was a result of the need to attract and retain important customers, such as the Leighs, who brought revenue and kudos to the shopkeeper. Indeed, the local landowner was clearly seen as a significant economic fillip, a point made explicit when the Leigh's near neighbour, Lord Brooke was warned that his absence from Warwick Castle would 'lose him good interest'. ${ }^{89}$ This brings in a broader point: that 'local' was contingent and relational, with the Leighs clearly shopping 'locally' for everyday supplies whilst in London for the season.

\footnotetext{
${ }^{88}$ For example, SBT, DR18/5/5858. See also Clifford, 'Precious metalwork'.

${ }^{89}$ Borsay, 'Landed elite', p.287. The warning was about political interest, but the reason for its loss was clearly related to the patronage that Warwick was losing through Lord Brooke's absence from the town.
} 
In terms of wider processes and conceptions of consumption, it is possible to see the Leighs as modern consumers caught up in the changing material culture of the age, including a shift to fashionable but less durable furnishings and tableware. Cast in this light, they might be seen as part of an elite who, as McKendrick argues, formed the driving force behind a broader step-change in consumerism. However, whilst fashion was clearly an important consideration, their consumption was not marked by an endless pursuit of novelty; nor were they the frivolous and profligate fashion victims that emerge from middling sort critiques of aristocratic excess. Indeed, their spending appears to have been more closely aligned with notions of fashion that connoted rank and station - in a manner similar to that noted by Grieg for London's Beau Monde. Much of the Leigh's consumption was directed at marking their status through patronage, conspicuous consumption, and taste; priorities which helped to distinguish them from the middling sort. ${ }^{90}$ This is apparent from their engagement of high-class London craftsmen and their charitable giving, their spending on coaches and livery, and their purchases of books and scientific instruments. These were areas into which it was more difficult for the middling sort to follow, even assuming that they wished to do so. Moreover, there was a strong current of traditional, even 'dynastic' forms of consumption, most evident in the Leigh's desire to mark many goods with their coat of arms. This forces us to reexamine Corfield's assertion that traditional media for bolstering and projecting power - inheritance, title and lineage - were being replaced by more modern notions of consumption, display and taste. As Cannadine argues, these continued to be hugely important to the aristocracy, even as they were being layered with newer priorities and ideals. ${ }^{91}$ Further, it questions the position afforded to the aristocracy within wider models of consumer change. Certainly, the Leighs were active consumers who sought to reinforce their social and cultural standing through displays of splendour, fashion and taste; but, in maintaining their awareness of title and inheritance, they continued to draw on value systems and status markers unavailable to the middling sorts.

\footnotetext{
${ }_{90}$ This reflects the findings of Bourdieu in his analysis of elite and other consumption in post-war France: see Bourdieu, Distinction.

${ }^{91}$ Corfield, 'Class by name and number'; Canndadine, Lords and Landlords.
} 


\section{Footnote references}

Beard, G., Georgian Craftsmen and their Work (London, 1966).

Beard, G., Decorative Plasterwork in Great Britain(London, 1975)

Beard, G., Upholsterers and Interior Furnishing in England, 1530-1840 (New Haven, 1997).

Beckett, J., The Aristocracy in England, 1660-1914(Oxford, 1986).

Berg, M. and Clifford, H. (eds), Consumers and Luxury. Consumer Culture in Europe, 1650-1850 (Manchester, 1999).

Berg, M., Luxury and Pleasure in Eighteenth-Century Britain (Oxford, 2005).

Berry, H., 'Polite consumption: shopping in eighteenth-century England', Transactions of the Royal Historical Society, 12 (2002), pp.375-94.

Berry, H., 'Prudent luxury: the Metropolitan tastes of Judith Baker, Durham gentlewoman', in P. Lane and R. Sweet (eds), Out of Town: Women and Urban Life in Eighteenth-Century Britain (Aldershot: 2005), pp.130-54.

Black, J., A Subject for Taste (London, 2005).

Blondé, B., 'Cities in decline and the dawn of a consumer society. Antwerp in the $17^{\text {th }}-18^{\text {th }}$ centuries', in B. Blondé, E. Briot, N Coquery and L. Van Aert (eds) Retailers and Consumer Changes in Early Modern Europe (Tours, 2005), pp.37-52

Blondé, B., 'Conflicting consumption models? The symbolic meaning o possessions and consumption amongst the Antwerp nobility at the end of the eighteenth century', in B. Blondé, N. Coquery, J. Stobart and I. Van Damme (eds) Fashioning Old and New. Changing Consumer Patterns in Western Europe, 1650-1900(Turnhout, 2009), pp.61-80.

Blondé, B. and Van Damme, I., 'Retail growth and consumer changes in a declining urban economy: Antwerp (1650-1750), Economic History Review, [only available in OnlineEarly]

Borsay, P., The English Urban Renaissance. Culture and Society in the Provincial Town, 1660-1770 (Oxford, 1989).

Borsay, P., 'The landed elite and provincial towns in Britain, 1660-1800', The Georgian Group Journal, xiii (2003), pp.281-94.

Bourdieu, P., Distinction. A Social Critique of Judgement and Taste (London, 1986)

Brewer, J. and Porter, R. (eds) Consumption and the World of Goods (London, 1993).

Brewer, J., Pleasures of the Imagination. English Culture in the Eighteenth Century (Chicago, 1997).

Burke, P., The Historical Anthropology of Early Modern Italy. Essays on perception and Communication (Cambridge, 1987). 
Canadine, D. Lords and Landlords: the Aristocracy and the Towns, 1774-1967 (1980).

Christie, C., The British Country House in the Eighteenth Century (Manchester, 2000).

Clifford, H., 'A commerce in things: the value of precious metalwork in early modern England', in M. Berg and H. Clifford (eds), Consumers and Luxury. Consumer Culture in Europe, 1650-1850 (Manchester, 1999), pp.147-68.

Corfield, P.J., 'Class by name and number in eighteenth-century Britain', in P. J. Corfield (ed.), Language, History and Class (Oxford, 1991), pp.101-30.

Cox, N., The Complete Tradesman: A Study of Retailing, 1550-1820 (Aldershot, 2000).

De Vries, J., The Industrious Revolution: Consumer Behavior and the Household Economy, 1650 to the Present (Cambridge, 2008).

Gomme, A., 'Abbey into palace: a lesser Wilton?', in R. Bearman (ed.), Stoneleigh Abbey. The House, Its Owners, Its Lands (Stoneleigh, 2004), pp.82-115.

Grieg, H., 'Leading the fashion: the material culture of London's beau monde', in J. Styles and A. Vickery (eds), Gender, Taste and Material Culture in Britain and North America 1700-1830 (New Haven, 2006), pp.293-313.

Guilding, R., Marble Mania: Sculpture Galleries in England, 1640-1840 (London, 2001).

Habbakuk, H. J., Marriage, Debt, and the Estates System: English Landownership 1650-1950 (Oxford, 1994).

Harris, L., (ed.), Robert Adam and Kedleston: The Making of a Neo-Classical Masterpiece (London, 1987).

Heal, F. and Holmes, G., The Gentry in England and Wales (Basingstoke, 1994).

Klein, L., 'Politeness for Plebes. Consumption and Social Identity in Early Eighteenth-Century England', in J. Brewer and A. Bermingham (eds) The Culture of Consumption: Image, Object, Text (London, 1995), pp.362-82.

MacDonald, M., “Not unmarked by some eccentricities”: the Leigh family of Stoneleigh Abbey', in R. Bearman (ed.), Stoneleigh Abbey. The House, Its Owners, Its Lands (Stoneleigh, 2004), pp.131-62.

McCracken, G., Culture and Consumption. New Approaches to the Symbolic Character of Consumer Goods and Activities (Bloomington, 1988).

McKendrick, N., 'The consumer revolution of eighteenth-century England', in N. McKendrick, J. Brewer and J.H. Plumb (eds), The Birth of a Consumer Society (London, 1982), pp.9-33.

Mitchell, B., Abstract of British Historical Statistics (Cambridge, 1962). 
Morris, R., 'From monastery to country house: an architectural history of Stoneleigh Abbey, 1156c.1660', in R. Bearman (ed.), Stoneleigh Abbey. The House, Its Owners, Its Lands (Stoneleigh, 2004), pp.15-61.

Mui, H.-C. and Mui, L., Shops and Shopkeeping in Eighteenth-Century England (London, 1989)

Overton, M. 'Prices from probate inventories', in T. Arkell, N. Evans and N. Goose (eds) When Death Do Us Part. Understanding and Interpreting the Probate Records of Early Modern England (Oxford, 2000), pp.120-41.

Overton, M, Whittle, J., Deane, D. and Hann, A., Production and Consumption in English Households, 1600-1750 (London, 2004).

Peck, L., Consuming Splendor: Society and Culture in Seventeenth-Century England (Cambridge, 2005).

Pointon, M., 'Jewellery in eighteenth-century England', in M. Berg and H. Clifford (eds), Consumers and Luxury. Consumer Culture in Europe, 1650-1850 (Manchester, 1999), pp.147-68.

Reid, P. H., 'Proto-bibliophiles amongst the English aristocracy, 1500-1700'. Library History, 18:1 (2002), pp.25-38.

Simmel, G., On individuality and Social Forms: Selected Writings (ed. D. Levine, Chicago, 1971).

Smith, W.D., Consumption and the Making of Respectability, (London, 2003).

Stobart, J., 'Clothes, cabinets and carriages: second-hand dealing in eighteenth-century England', in B. Blondé, P. Stabel, J. Stobart and I. Van Damme (eds) Buyers and Sellers. Retail Circuits and Practices in Medieval and Early Modern Europe (Turnhout, 2006), pp.225-44.

Stobart, J., Spend, Spend, Spend! A History of Shopping (Stroud, 2008).

Stobart, J., Hann, A. and Morgan, V., Spaces of Consumption. Leisure and Shopping in the English Town, c.1660-1830 (London, 2007).

Stone, L. \& Stone, J.C., An Open Elite? England 1540-1880 (Oxford, 1986).

Styles, J., The Dress of the People (New Haven, 2007)

Symonds, J. (ed.), Table Settings: the Material Culture and Social Context of Dining, A.D.1700-1900 (Oxford, 2010).

Veblen, T., The Theory of the Leisure Class: an Economic Study of Institutions (Basingstoke, 1912).

Vickery, A., “Neat and not too showey”: words and wallpaper in Regency London', in J. Styles and A. Vickery (eds), Gender, Taste and Material Culture in Britain and North America 1700-1830 (New Haven, 2006), pp.201-22

Vickery, A., The Gentleman's Daughter (New Haven, 1997).

Weatherill, L., Consumer Behaviour and Material Culture (second edition, London, 1996). 
Williams, J. D., 'The noble household as a unit of consumption: the Audley End experience, 17651797', Essex Archaeology and History, 23 (1992), pp.67-78.

Wilson, M.I., William Kent: Architect, Designer, Painter, Gardener, 1685-1748 (London, 1984).

Wilson, R. and Mackley, A., The Building of the English Country House (London, 2000). 